\title{
Movements of the white shark Carcharodon carcharias in the North Atlantic Ocean
}

\author{
G. B. Skomal ${ }^{1, *}$, C. D. Braun ${ }^{2,3}$, J. H. Chisholm ${ }^{1}$, S. R. Thorrold ${ }^{4}$ \\ ${ }^{1}$ Massachusetts Division of Marine Fisheries, 836 South Rodney French Blvd., New Bedford, MA 02744, USA \\ ${ }^{2}$ MIT-WHOI Joint Program in Oceanography, Massachusetts Institute of Technology, Cambridge, MA 02139, USA \\ ${ }^{3}$ MIT-WHOI Joint Program in Oceanography, Woods Hole Oceanographic Institution, Woods Hole, MA 02543, USA \\ ${ }^{4}$ Biology Department, Woods Hole Oceanographic Institution, Woods Hole, MA 02543, USA
}

\begin{abstract}
In the western North Atlantic, much of what is known about the movement ecology of the white shark Carcharodon carcharias is based on historical fisheries-dependent catch records, which portray a shelf-oriented species that moves north and south seasonally. In this study, we tagged 32 white sharks (16 females, 7 males, 9 unknown), ranging from 2.4 to $5.2 \mathrm{~m}$ total length, with satellitebased tags to investigate broad-scale movements in the North Atlantic. Based on 10427 days of tracking data, we found that white sharks are more broadly distributed, both horizontally and vertically, throughout the North Atlantic than previously understood, exhibiting an ontogenetic shift from near-coastal, shelf-oriented habitat to pelagic habitat with frequent excursions to mesopelagic depths. During the coastal phase, white sharks migrated seasonally from the northeast shelf in the summer to overwintering habitat off the southeastern US and the Gulf of Mexico, spending $95 \%$ of their time at $<50 \mathrm{~m}$ depth. During the pelagic phase, subadult and adult white sharks exhibited wide-ranging movements during the fall, winter, and spring into the broader Atlantic over a $30^{\circ}$ latitudinal range and as far east as the Azores. These sharks moved daily to depths of up to $1128 \mathrm{~m}$, spending significant time at specific mesopelagic depth zones through a temperature range of 1.6 to $30.4^{\circ} \mathrm{C}$. We believe these movements are associated with offshore foraging facilitated by the thermal physiology of the species. Our findings extend the known essential habitat for the white shark in the North Atlantic beyond existing protection, with implications for future conservation.
\end{abstract}

${ }^{*}$ Corresponding author: gregory.skomal@state.ma.us

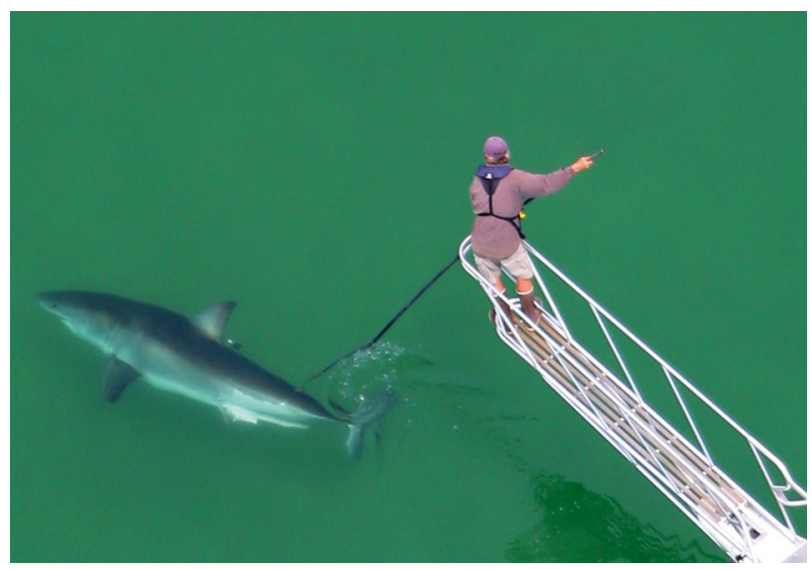

A researcher tags a white shark while it is free-swimming off the coast of Cape Cod, MA, USA.

Photo: Wayne Davis

KEY WORDS: White shark - Habitat utilization · Behavior · Migration · Carcharodon carcharias · Life history

\section{INTRODUCTION}

The white shark Carcharodon carcharias is welldocumented in the western North Atlantic Ocean from Newfoundland to the Gulf of Mexico, including The Bahamas and parts of the Caribbean (Bigelow \& Schroeder 1948, Templeman 1963, Compagno 1984, Casey \& Pratt 1985). Yet, despite a well-established presence, efforts to study its life history and ecology have been hampered by the inability of researchers

() The authors 2017. Open Access under Creative Commons by Attribution Licence. Use, distribution and reproduction are unrestricted. Authors and original publication must be credited. 
to predictably encounter these sharks. Indeed, much of what is known of this species in the North Atlantic comes from the analysis of distribution records (Templeman 1963, Casey \& Pratt 1985), rare behavioral observations (Carey et al. 1982, Pratt et al. 1982), and the opportunistic examination of dead specimens (Pratt 1996).

The distribution of the white shark in the western North Atlantic (WNA) has been reviewed by Casey \& Pratt (1985) and, more recently, Curtis et al. (2014) based on fisheries interactions, confirmed sightings, and published accounts. The rarity of this species in the WNA is exemplified by the observation that white sharks represented only $0.04 \%$ of the sharks taken by over 2.1 million hooks of pelagic longline effort from the Grand Banks to the Gulf of Mexico (1963-1983, Casey \& Pratt 1985) and the resulting compilation of only 649 records during the period 1800-2010 (Curtis et al. 2014). Nonetheless, these authors concluded that white sharks in the WNA are most abundant in continental shelf waters and exhibit seasonal movements, presumably mediated by water temperature, into northern latitudes during the summer months (Casey \& Pratt 1985, Curtis et al. 2014). However, as noted by Curtis et al. (2014), the use of fisheries-dependent data to describe the distribution of a species can be biased by a number of factors including the temporal and spatial distribution of fishing effort and catchability. Hence, these records and the seasonal movements derived from them may not accurately reflect the entire distribution and movement ecology of the white shark in the WNA.

In the Pacific and Indian oceans, the ecology of the white shark is relatively well studied because individuals aggregate on a seasonal basis at large pinniped colonies for feeding (Klimley \& Ainley 1996, Domeier 2012). The high seasonal abundance of white sharks near seal and sea lion colonies has also allowed researchers in these regions to study the horizontal and vertical movements of white sharks over broad spatial and temporal scales using satellitebased tag technology. For instance, white sharks have been shown to exhibit deep-diving behavior associated with coastal and ocean basin-scale movements (Boustany et al. 2002, Bonfil et al. 2005, Bruce et al. 2006, Weng et al. 2007a,b, Domeier \& NasbyLucas 2008, 2013, Nasby-Lucas et al. 2009, Jorgensen et al. 2010, Duffy et al. 2012). This diving behavior has been linked to feeding (Domeier \& Nasby-Lucas 2008, Nasby-Lucas et al. 2009) and reproduction (Jorgensen et al. 2012), but with only limited evidence for either hypothesis.
The only horizontal and vertical movement observations of white sharks in the North Atlantic come from a single acoustic tracking study conducted by Carey et al. (1982). These researchers acoustically tagged a $4.6 \mathrm{~m}$ total length (TL) white shark that was scavenging a fin whale Balaenoptera physalus carcass $39 \mathrm{~km}$ southwest of Montauk Point, New York, and tracked the shark for $83 \mathrm{~h}$ as it moved $190 \mathrm{~km}$ southwest along the 25 fathom (46 m) bathymetric curve. The shark remained largely associated with the thermocline at approximately 10 to $20 \mathrm{~m}$, but made periodic excursions to the bottom. At the time, Carey et al. (1982) noted that 'the seals, sea lions, and elephant seals, which are common items in the diet of white sharks in other regions, are not available' in the WNA. Hence, they concluded that the observed diving behavior may be associated with searching for dead whales, which were considered an important food resource for large white sharks ( $>3 \mathrm{~m}$ TL) on the continental shelf. Indeed, the presence of scavenging white sharks on whale carcasses is well-documented in this region (Pratt et al. 1982).

While seal populations were once decimated in the WNA, the protection of marine mammals afforded by the US Marine Mammal Protection Act has led to a rebound in the Atlantic gray seal Halichoerus grypus population (NMFS 2009, Wood LaFond 2009). There is evidence that white sharks have, in turn, expanded their diet in response to regional changes in seal abundance (Skomal et al. 2012). The predictable abundance of white sharks off the coast of Cape Cod, Massachusetts, provided a research opportunity to study the ecology and life history of this species in the North Atlantic Ocean. The objective of the current study was to deploy satellite-based tag technology on white sharks to uncover, for the first time, the broad-scale 3-dimensional movements of white sharks in the North Atlantic, and relate them to the natural history of this species.

\section{MATERIALS AND METHODS}

\section{Tagging}

White sharks were tagged off the coasts of Cape Cod, Massachusetts $(\mathrm{n}=31$ ) during the summers (July to October) of 2009 to 2014 and Jacksonville, Florida ( $\mathrm{n}=1$ ) in March, 2013 (Table 1). We deployed pop-up satellite archival transmitting (PSAT) tags (models MK10-PAT [MK10, $\mathrm{n}=7$ ], miniPAT [mP, $\mathrm{n}=$ 16], MK10AF [n = 7], Wildlife Computers; model SeaTag-MOD [STM, n=4], Desert Star Systems LLC) 


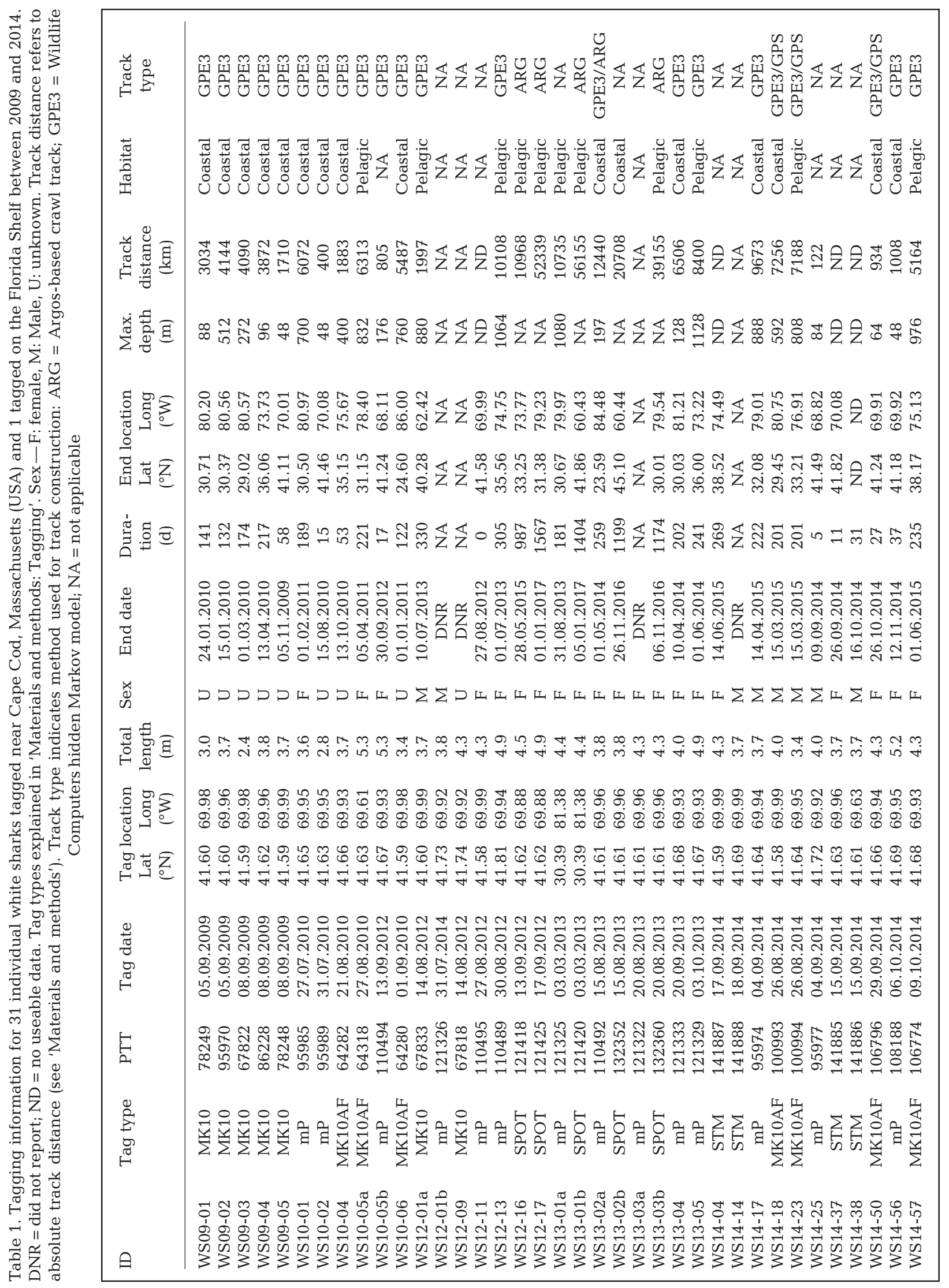


on free-swimming white sharks using a modified harpoon technique with the assistance of a spotter plane (Chaprales et al. 1998). Tags were tethered with stainless steel wire to an intramuscular T-bar style spear tip. Each tag was programmed to record depth (MK10, MK10AF: range $=0-1000 \mathrm{~m}$, resolution $=$ $0.5 \mathrm{~m} \pm 1.0 \%$; $\mathrm{mP}: 0-1700 \mathrm{~m}, 0.5 \mathrm{~m} \pm 1.0 \%$ ), water temperature $\left(-40\right.$ to $\left.+60^{\circ} \mathrm{C}_{i} 0.05 \pm 0.1^{\circ} \mathrm{C}\right)$, and light level $\left(470 \mathrm{~nm}\right.$, logarithmic range $=5 \times 10^{-12} \mathrm{~W} \mathrm{~cm}^{-2}$ to $5 \times 10^{-2} \mathrm{~W} \mathrm{~cm}^{-2}$ ) every 10 (MK10, MK10AF) or 15 $(\mathrm{mP})$ seconds. Archived depth and temperature data were compiled and aggregated into 14 (MK10, MK10AF) or $12(\mathrm{mP})$ bins every 12 (MK10, MK10AF) or $24(\mathrm{mP}) \mathrm{h}$. In addition, depth-temperature profiles were compiled over a 12 (MK10, MK10AF) or $24(\mathrm{mP}) \mathrm{h}$ period, and light levels were concurrently recorded with depth to incorporate attenuation in post-processing. The PSAT tags were programmed to detach after periods of 122 to $308 \mathrm{~d}$ and transmit preprocessed data through the Argos satellite system. All shark TLs were estimated from aerial photos using the vessel pulpit length $(320 \mathrm{~cm})$ for scale. Given the vertical distance from the pulpit to the shark of 120 to $180 \mathrm{~cm}$ (depending on shark depth), shark size was likely underestimated and was subsequently considered a minimum estimate. Maturity classes (juvenile $[<3.0 \mathrm{~m}$ ], subadult [male: $3.0-3.5 \mathrm{~m}$, female: $3.0-4.8 \mathrm{~m}$ ], adult [male: $\geq 3.5 \mathrm{~m}$, female: $\geq 4.8 \mathrm{~m}]$ ) were assigned to tagged sharks as defined by Bruce \& Bradford (2012), based on previously published sex-specific estimates of size at maturity (Francis 1996, Pratt 1996, Castro 2011).

Five white sharks were tagged with Smart Positioning or Temperature Transmitting (SPOT, model SPOT-257A, Wildlife Computers) tags (Table 1). These sharks were captured on handlines and tagged using the methods described by Domeier \& Nasby-Lucas (2012). In short, each shark was removed from the water after capture and a SPOT tag was affixed to the dorsal fin using nylon bolts. When at the surface, a wet/dry switch on the tag activated transmission to Argos satellites and a Doppler-based geoposition was calculated for the shark with associated location error. Three of these sharks were also tagged with a PSAT tag (Table 1).

\section{Data analysis}

Transmitted data from all PSAT tags were decoded with the manufacturer's cloud-based portal software before geolocation analysis was performed using the manufacturer's proprietary hidden Mar- kov model (HMM, WC-GPE3, Wildlife Computers) to estimate positions. This approach uses a gridded HMM that computes posterior probability distributions to estimate the most likely state (position) at each time point using light-levels, sea surface temperature, and bathymetric constraints. All default settings were accepted in the model. The speed setting in GPE3 is used to build daily diffusion kernels that govern allowable distance moved per day. Thus, while most published white shark speed estimates are 0.3 to $1.3 \mathrm{~m} \mathrm{~s}^{-1}$ (Strong et al. 1992, Klimley et al. 2001, Bruce et al. 2006, Johnson et al. 2009), we determined $2 \mathrm{~m} \mathrm{~s}^{-1}$ to be a suitable diffusion parameter in the model to avoid spatial constraint of model likelihoods should sharks in this study move a larger distance for any period of the track. Known locations (e.g. GPS positions from MK10AF tags) were included in the model (Table 1).

Locations of SPOT-tagged individuals were assigned error flags called location classes: LC 3, $<250 \mathrm{~m}_{i}$ LC 2, 250-500 m; LC 1, 500-1500 m; LC 0, $>1500 \mathrm{~m}$ for classes 3, 2, 1, 0, respectively. Additional classes A, B represented positions derived from less than 4 satellite messages and, therefore, resulted in no estimates of spatial accuracy. Location class Z positions were considered invalid and were removed from further analysis (CLS 2016). The remaining positions, after removal of $\mathrm{Z}$ class positions, were filtered using a speed filter $\left(2 \mathrm{~m} \mathrm{~s}^{-1}\right)$ from the 'trip' package (Sumner \& Luque 2015) in the R Statistical Environment (R Development Core Team 2015). Individuals were classified as 'coastal' or 'pelagic' based on observed movements relative to bathymetry. Total track distances were calculated using great circle distance between track locations averaged daily.

Dive data analysis for PSAT tags was performed by aggregating depth and temperature bins to the common bins among all individuals. Time-at-depth (TAD) bin limits were aggregated to $<10,10-25$, 25-50, 50-100, 100-200, 200-400, 400-600, 600-800, and $>800 \mathrm{~m}$, and time-at-temperature (TAT) were aggregated to $<7^{\circ}, 7-9,9-11,11-13,13-15,15-17$, $17-19,19-21,21-23,23-25,25-27$, and $>27^{\circ} \mathrm{C}$. Consequently, sharks 10-01 and 10-02 were removed from TAD analysis and sharks 10-05b, 12-13, and 1417 from TAT analysis due to incompatible, non-overlapping bins. A spatial average of daily locations was then computed and daily summaries of dive data were assigned an 'onshore' or 'offshore' flag based on the $200 \mathrm{~m}$ depth contour along the continental shelf of the eastern US. 


\section{RESULTS}

Of the 37 tags deployed on 32 individual white sharks, we received data from 27 (84\%) PSAT tags and all 5 SPOT tags showing the movements of 29 individuals (Table 1 ). These results included data from a shark (WS10-05) tagged twice with a PSAT tag (August, 2010 and September, 2012) and 2 sharks (WS13-01, WS13-02) double-tagged with both a PSAT tag and a SPOT tag. Estimated sizes of tagged sharks ranged from 2.4 to $5.3 \mathrm{~m}$ TL (mean $\pm \mathrm{SD}, 4.0 \pm$ $0.65 \mathrm{~m}$ ). We tagged 16 females (9 subadults, 7 adults, $4.4 \pm 0.53 \mathrm{~m})$ and 7 males ( 1 subadult, 6 adults, $3.8 \pm 0.19 \mathrm{~m}$ ), with a resulting sex ratio (M:F) of 0.44 (Fig. 1). We were unable to determine sex of the remaining 9 individuals (3 juveniles, 6 subadults/adults).

Deployment durations of the PSAT tags $(\mathrm{n}=24)$ ranged from 0 to $330 \mathrm{~d}$ (mean $=151 \mathrm{~d}$ ) and totaled 4096 tracking days during which individuals moved up to $12440 \mathrm{~km}$ (mean $=4973 \mathrm{~km}$; range 122-12440 km) and dove to a maximum depth of $1128 \mathrm{~m}$ (Table 1). SPOT tags $(\mathrm{n}=5)$ spanned a total of 6331 tracking days (with some temporal gaps between transmissions) with individual movements as far as $56155 \mathrm{~km}$ in $3.8 \mathrm{yr}$ (WS13-01) (mean = 35865 km; range 10968-56155 km). Movements derived from SPOT tags also provided accurate position information for 2 individuals (WS13-01, WS13-02) also tagged with PSAT tags.

The tracks indicated contrasting movement patterns among individuals that may reflect ontogenetic changes in habitat use. Smaller individuals $(<3 \mathrm{~m})$ tended to remain on the continental shelf (Figs. $2 \& 3$ ) while larger individuals $(>3 \mathrm{~m}$ ) more often exhibited wide-ranging movements through offshore, pelagic habitats (Figs. $2 \& 4$ ). Based on previously published estimates of size at maturity (Francis 1996, Pratt 1996, Castro 2011) and life history stages as defined by Bruce \& Bradford (2012), the shelf-oriented sharks (n $=16)$ comprised juvenile $(n=3)$, subadult $(n=9)$, and adult $(n=4)$ sharks of both sexes, while those that moved into pelagic habitats $(\mathrm{n}=10)$ were subadults (1 male, 2 females) and adults (1 male, 6 females) of both sexes (Fig. 2).

Those individuals largely restricted to shelf habitats migrated seasonally between the tagging location and northern latitudes, including the Gulf of Maine, in the summer, through the Mid-Atlantic
Bight and past Cape Hatteras, North Carolina in the fall, to the South Atlantic Bight as far as the Gulf of Mexico during the winter and spring (Figs. $3 \& 5$ ). Of the 26 tagged white sharks yielding movement data, $62 \%$ remained exclusively on the continental shelf for their entire tracks (up to $3 \mathrm{yr}$ ). The seasonal transition from overwintering habitat off southeastern USA (North Carolina, South Carolina, Georgia, and Florida) was relatively rapid, with little time spent in between (Mid-Atlantic Bight) while the migration from summer habitat off the northeastern US during the fall months was more gradual (Fig. 6).

In contrast, individuals that moved off the continental shelf into offshore habitats demonstrated a much less defined seasonal pattern (Figs. 4 \& 5), independent of year. Movements were wide-ranging over the WNA during most of the year, with the exception of the summer, during which the sharks were shelf-oriented (Figs. 4 \& 5). However, in con-

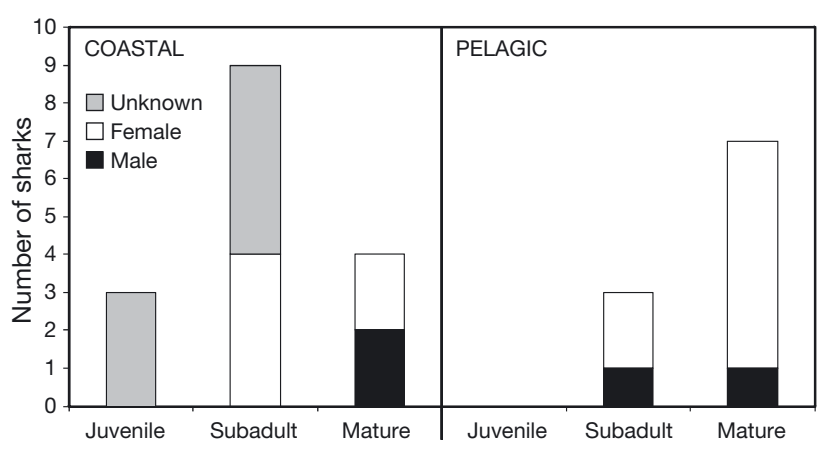

Fig. 2. Frequency distribution of individual white sharks by life history stage and habitat preference 


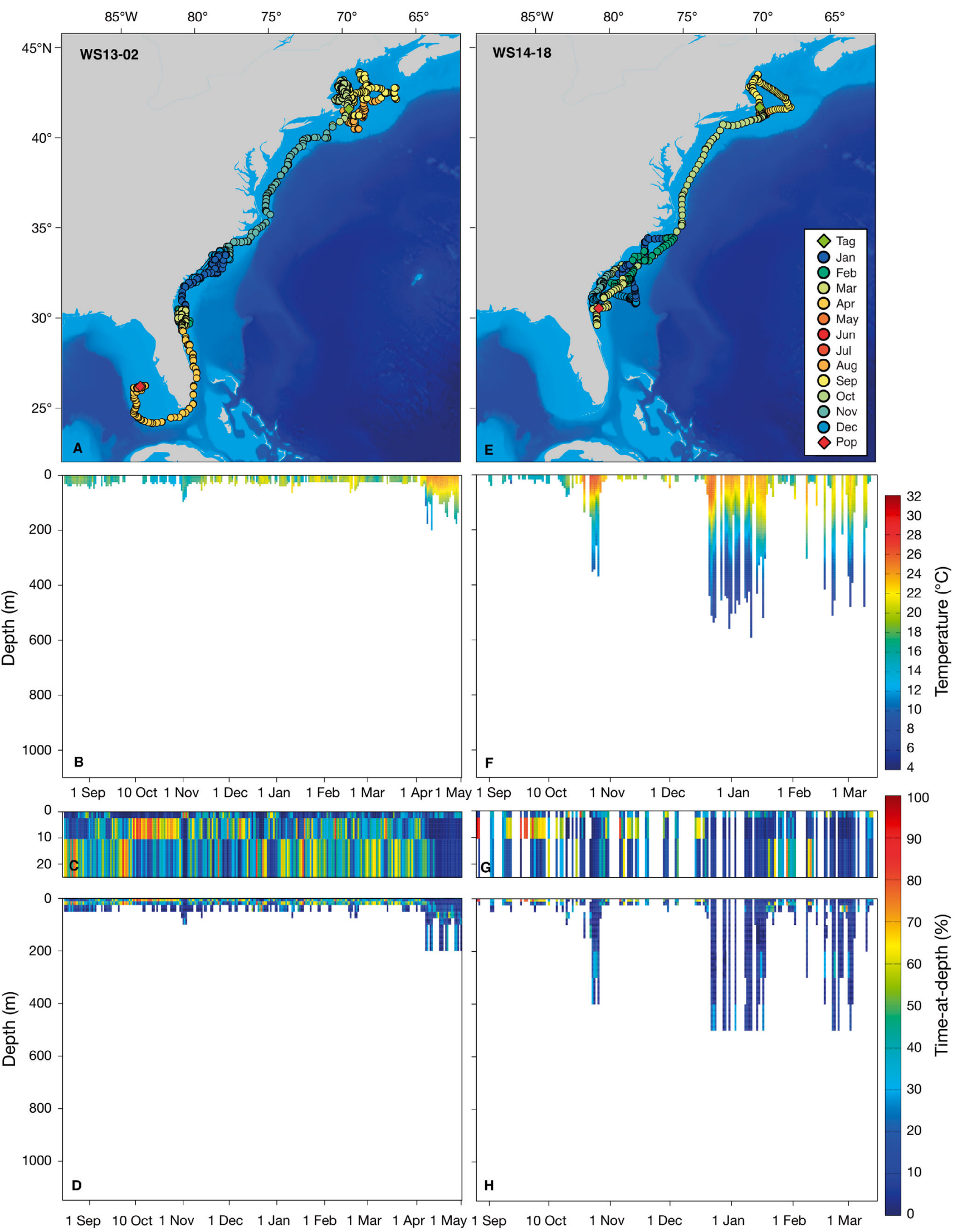

Fig. 3. $(A, E)$ Most probable track, $(B, F)$ daily depth-temperature profiles, and $(C, D, G, H)$ daily time-at-depth utilization for tagged white sharks WS13-02 (2013-2014) and WS14-18 (2014-2015) over the duration of tag deployment-(C) and (G) are scaled to facilitate observation of surface occupancy in (D) and (H), respectively. Both tracks are GPE3 model-estimated tracks using known locations, when available ( $\mathrm{n}=12$ and $\mathrm{n}=2$ for WS13-02 and WS14-18, respectively) 

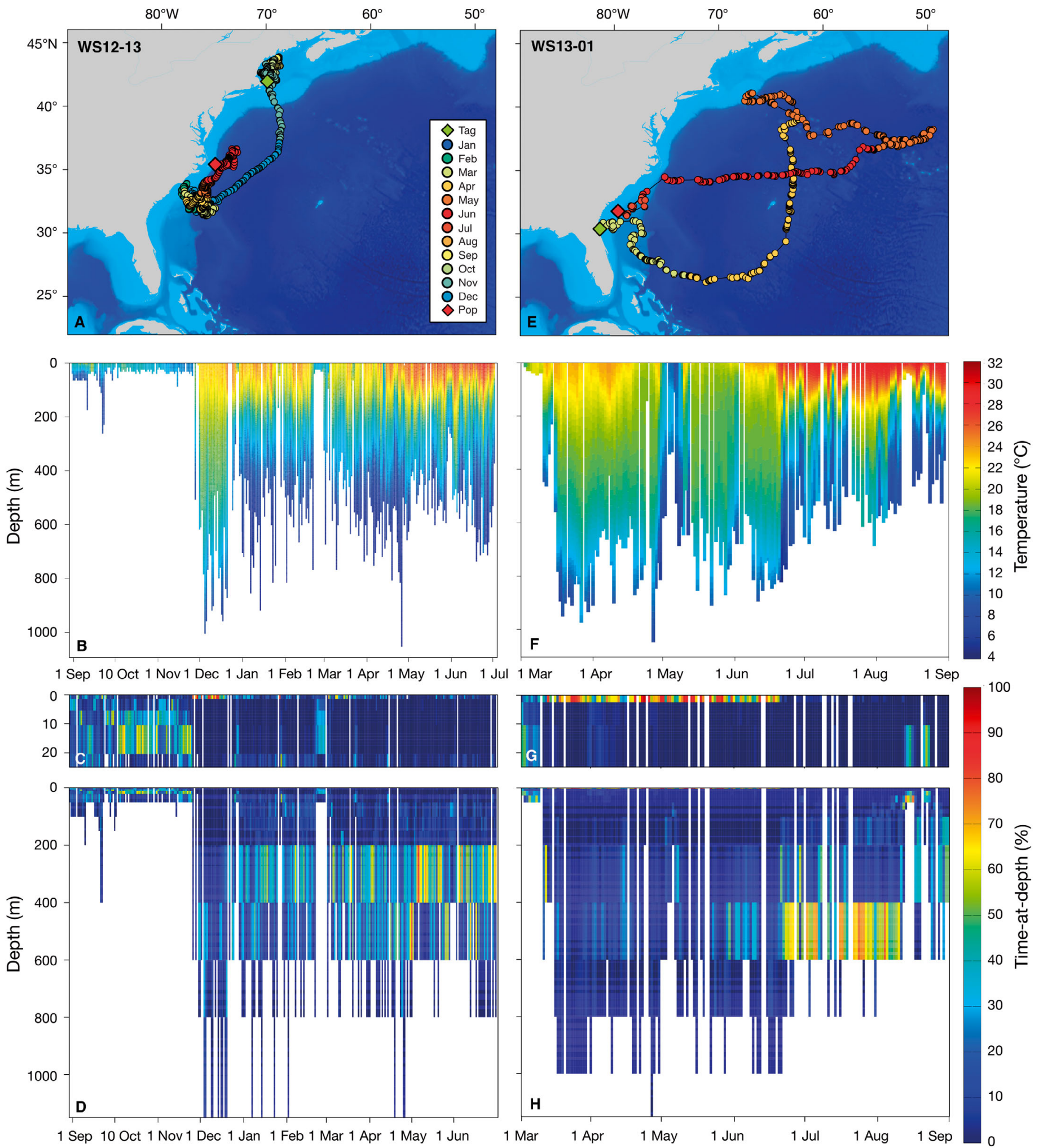

Fig. 4. (A,E) Estimated movements, $(B, F)$ daily depth-temperature profiles, and $(C, D, G, H)$ daily time-at-depth utilization for tagged white sharks WS12-13 (2012-2013) and WS13-01 (2013) over the duration of tag deployment - (C) and (G) are scaled to facilitate observation of surface occupancy in (D) and (H), respectively. The WS12-13 track was estimated using GPE3, and WS13-01 movements are Argos-based positions from a SPOT tag 


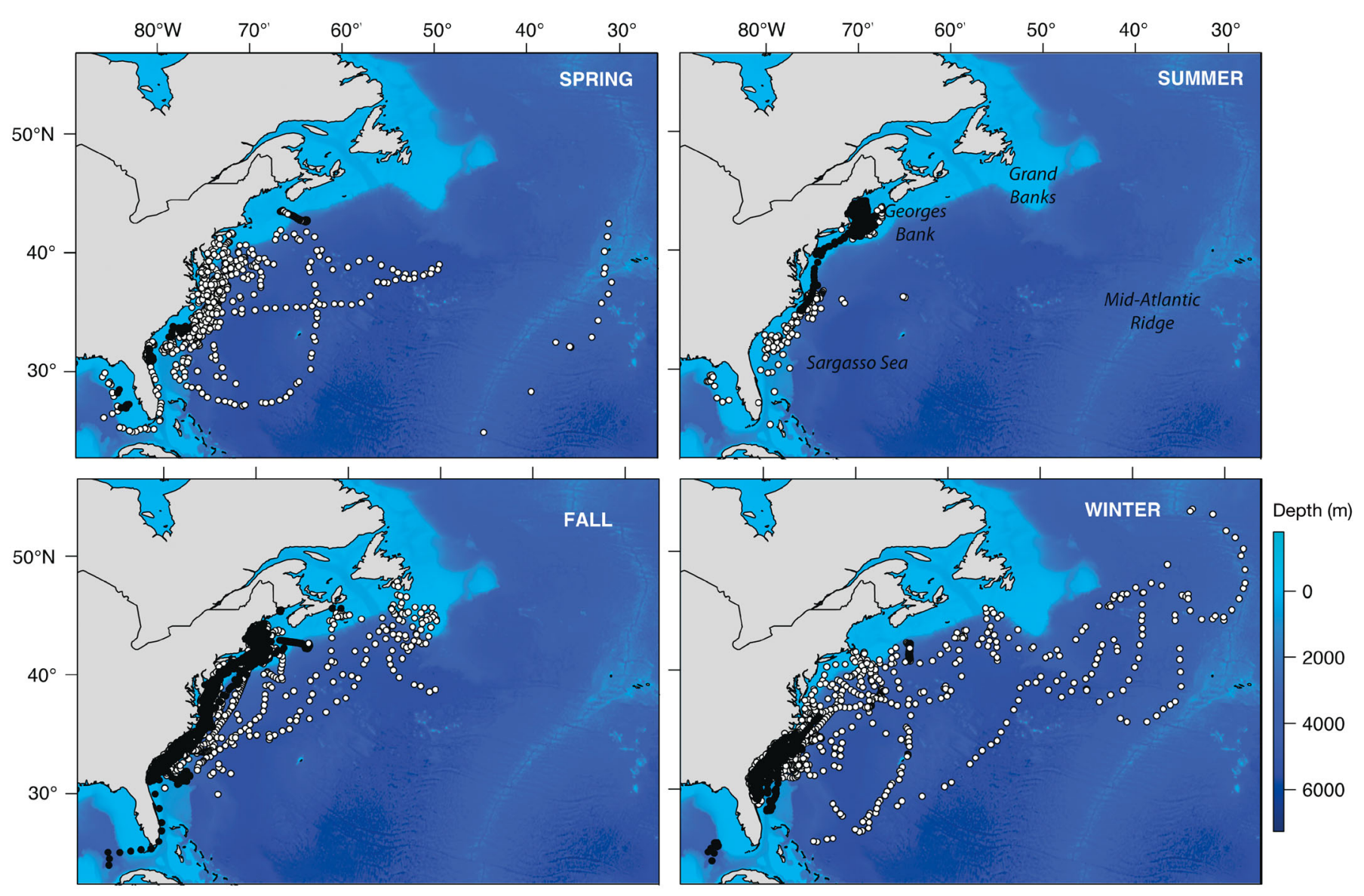

Fig. 5. Seasonal movements of white sharks tagged in the western North Atlantic, 2009-2014, generated from both SPOT $(\mathrm{n}=5)$ and PSAT $(\mathrm{n}=24)$ tags and broken down by individuals demonstrating coastal (black circles) vs. pelagic (white circles) behavior with associated bathymetry. Seasons are based on the lunar calendar (mo/d: Spring, 3/20-6/19; Summer, 6/20-9/19; Fall, 9/20-12/19; Winter, 12/20-3/19)

trast to sharks that exhibited only shelf-oriented behavior, subadult and adult sharks returning from pelagic habitat in the summer were all along the coast from the Gulf of Mexico to New England (Fig. 5). During the fall, white sharks ranged from off the coast of Georgia into the Sargasso Sea to as far north and east as Newfoundland, Canada, and the Grand Banks (Fig. 5). During the winter and spring months, these individuals occupied a $30^{\circ}$ latitudinal range $\left(25-55^{\circ} \mathrm{N}\right)$ from The Bahamas to an area $930 \mathrm{~km}$ southeast of Greenland; sea surface temperatures spanned $28^{\circ} \mathrm{C}\left(2-30^{\circ} \mathrm{C}\right)$ over this range. Longitudinally, these white sharks ranged from the US coastline to the Mid-Atlantic Ridge and one of the sharks (WS13-01) moved into the eastern North Atlantic $\left(30^{\circ} \mathrm{W}\right)$ passing within $30 \mathrm{~km}$ of the island of Flores in the Azores (Fig. 5). Three individuals, 2 considered 'coastal' (WS10-06, WS13-02) and one 'pelagic' (WS13-03), also moved into the Gulf of Mexico during winter (WS10-06) or early spring (WS13-02, WS13-03) (Figs. 3 \& 5).

PSAT-tagged individuals $(\mathrm{n}=24)$ transmitted $>3000 \mathrm{~d}$ of dive data, with water column temperatures of 4 to $32^{\circ} \mathrm{C}$, and dives as deep as $1128 \mathrm{~m}$ (3 ind. $>1000 \mathrm{~m}$ ) (Table 1). White sharks that remained on the shelf moved throughout the entire water column from the surface to the bottom, but were largely surface-oriented, spending, on average, 52 and $95 \%$ of their time in the top $10 \mathrm{~m}$ and $<50 \mathrm{~m}$, respectively (Figs. $3 \& 7$ ). These sharks traversed a broad temperature range $\left(4-32^{\circ} \mathrm{C}\right)$, but spent $95 \%$ of their time at $13-25^{\circ} \mathrm{C}$ (Fig. 8). In contrast, white sharks that moved offshore exhibited a daily bimodal pattern between the surface $(35 \%,<25 \mathrm{~m})$ and mesopelagic depths $(42 \%, 200-600$ m, Figs. 4 \& 7). During many of these vertical movements, white sharks appeared to target specific mesopelagic depths. For example, white sharks WS12-13 and WS13-01 spent up to $84 \%(20 \mathrm{~h})$ 


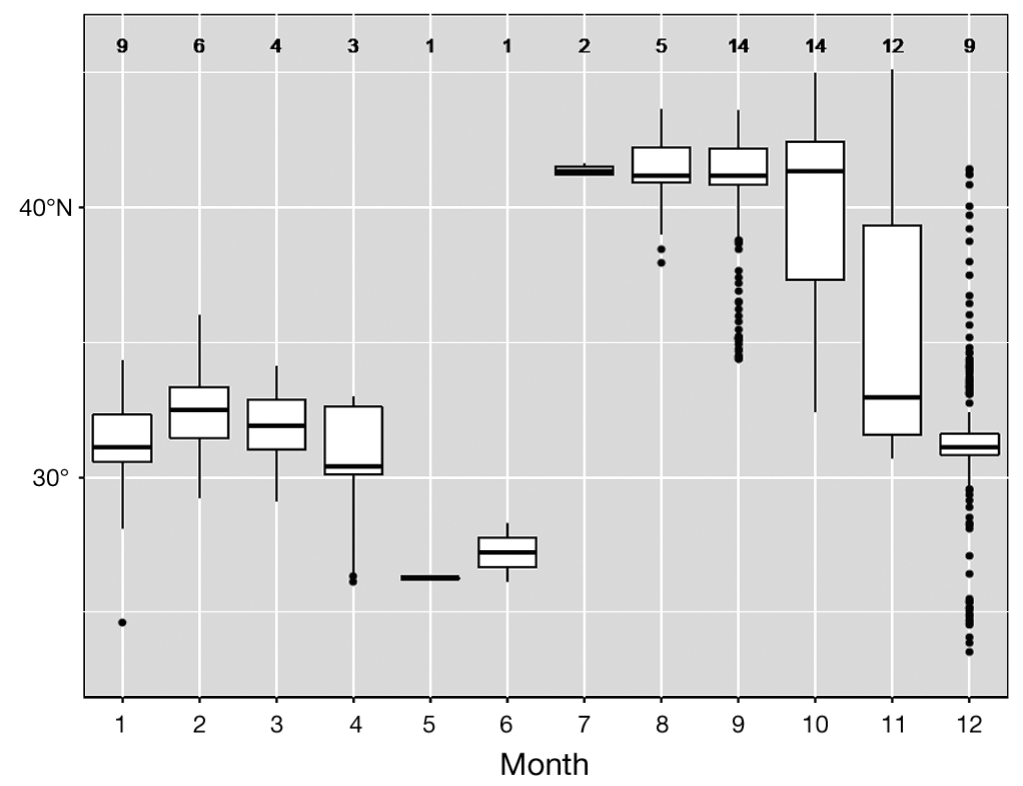

Fig. 6. Boxplot showing monthly latitudinal shift by shelf-oriented (coastal) white sharks tagged in the western North Atlantic, 2009-2014, generated from SPOT $(n=5)$ and PSAT $(n=24)$ tags. Sharks migrate northward rapidly during the late spring and southward more gradually during the autumn months. Boxes are interquartile range (IQR). Whiskers are $1.5 \times \mathrm{IQR}_{i}$ points beyond the whiskers represent outliers. Horizontal line within each box represents median monthly latitude. Numbers at top of panel: monthly sample size and $79.2 \%(19 \mathrm{~h})$ of each day at depths of $200-400 \mathrm{~m}$ and $400-600 \mathrm{~m}$, respectively, during their tracks (Fig. 4). The pelagic white sharks also exhibited a much flatter thermal distribution, spending $95 \%$ of their time, on average, in the temperature range of 11 to $27^{\circ} \mathrm{C}$ (Fig. 8). This indicates that individuals occupied a wider range of temperatures more frequently as they spent more time, horizontally and vertically, in both warmer and colder water when away from the shelf (Fig. 8).

\section{DISCUSSION}

While over 300 satellite tags have been deployed on white sharks across their circumglobal range before this study, there are currently no published tracking datasets in the Atlantic Ocean. In this study, we tagged juvenile, subadult, and adult white sharks of both sexes at a seasonal aggregation site off the coast of Cape Cod, Massachusetts,

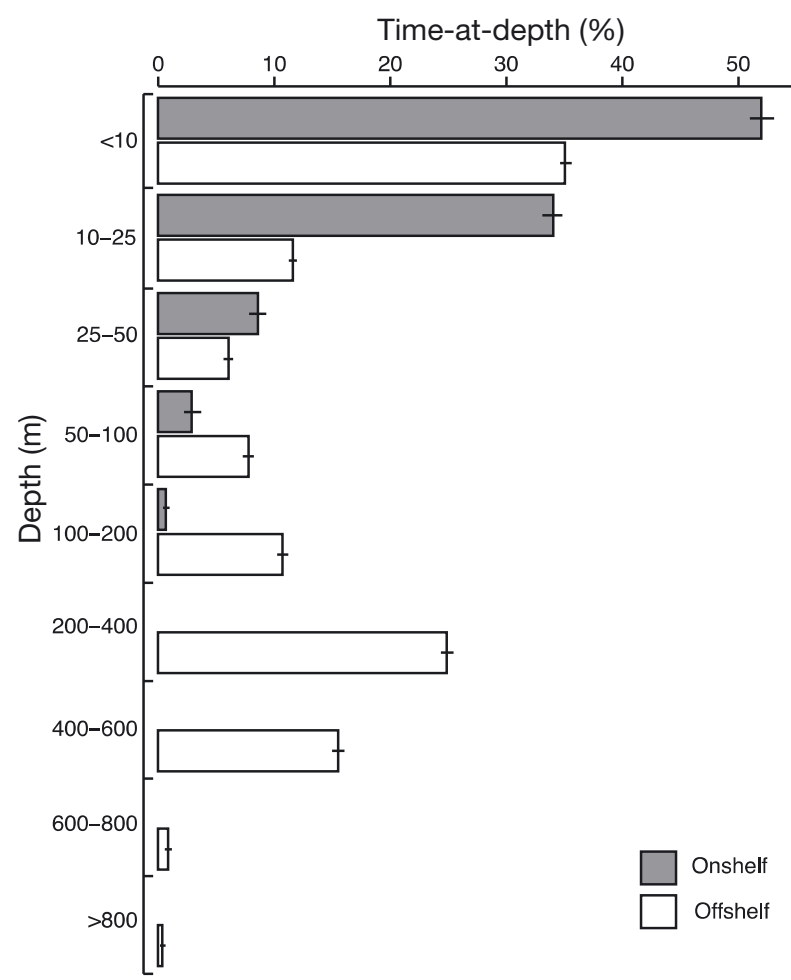

Fig. 7. Time-at-depth (mean \pm SE) histogram for on- and offshelf movements of PSAT-tagged white sharks. Shark positions were divided into spatial categories based on location relative to $200 \mathrm{~m}$ depth contour: Onshelf $<200 \mathrm{~m}$; Offshelf $>200 \mathrm{~m}$. Sharks 10-01 and 10-02 were removed from this dataset due to irregular summary bin spacing 60 and one adult female off Jacksonville, Florida. As has been the case in numerous studies on white shark movements in the Pacific and Indian oceans (Boustany et al. 2002, Bonfil et al. 2005, Bruce et al. 2006, Weng et al. 2007a,b, Jorgensen et al. 2010, 2012, Nasby-Lucas et al. 2009, Domeier 2012, Bruce \& Bradford 2012, Domeier \& Nasby-Lucas 2012, Duffy et al. 2012, Werry et al. 2012), we found that white sharks tagged in the Atlantic exhibited coastal, shelf-oriented movements as well as broad movements into oceanic habitat. Regardless of size, all of our tagged white sharks spent at least some proportion of their time on the continental shelf off the US east coast, but movements into oceanic waters beyond the shelf edge were restricted to the subadult and adult sharks of both sexes (>3 m TL, Fig. 2).

\section{Shelf movements}

The coastal-oriented sharks exhibited pronounced and consistent seasonal shifts in distribution, which were similar to previous observations derived from fisheries-dependent historical sightings data (Casey \& Pratt 1985, Curtis et al. 2014). During the summer, white sharks occupied Northeast Shelf waters be- 


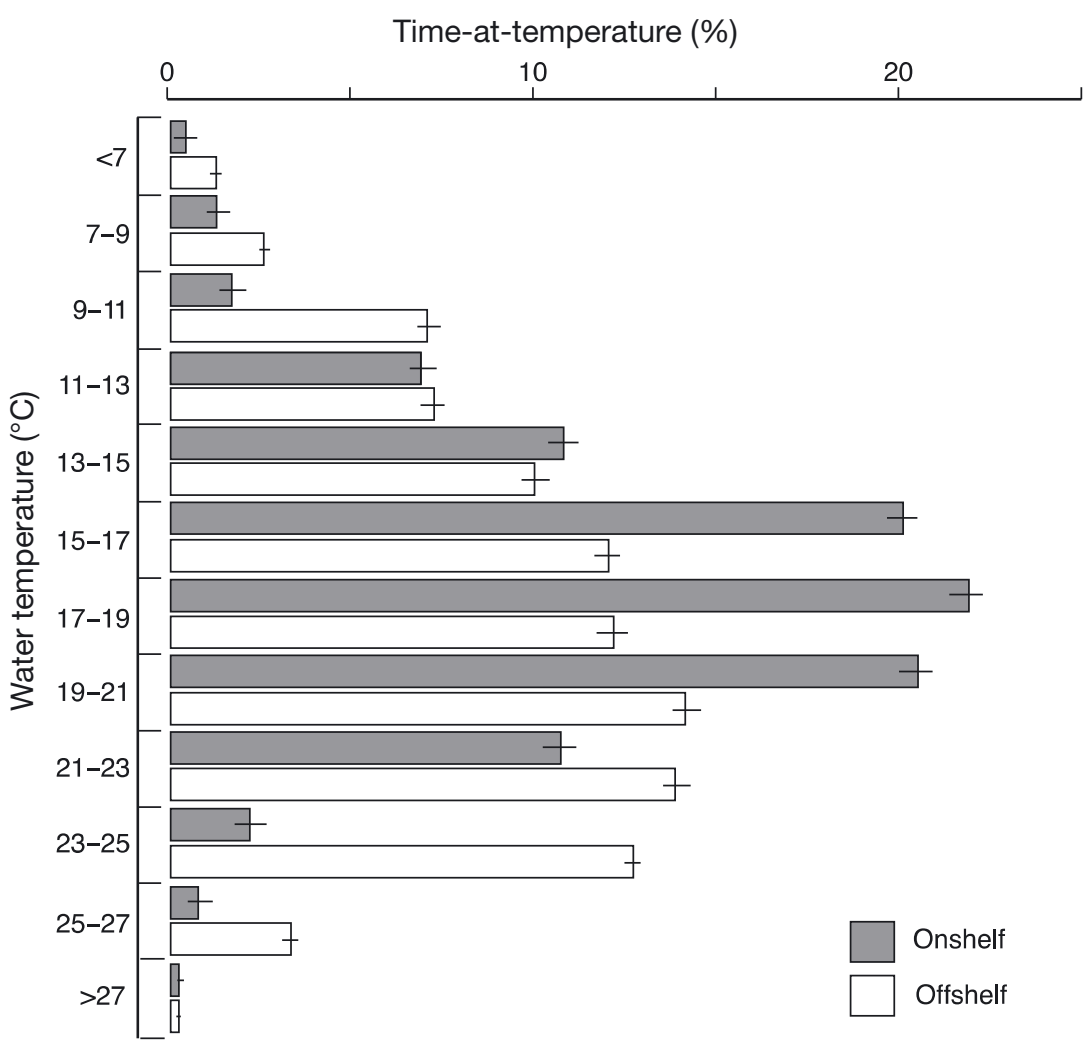

Fig. 8. Time-at-temperature (mean $\pm \mathrm{SE}$ ) histogram for on- and off-shelf movements of PSAT-tagged white sharks. Shark positions were divided into spatial categories based on 200 m contour. Sharks 10-05b, 12-13, and 14-17 were removed from this dataset due to irregular summary bin spacing

the bulk $(85 \%)$ of their time between $13-23^{\circ} \mathrm{C}$, which is almost identical to the preferred sea surface temperature ranges of $15-22^{\circ} \mathrm{C}$ and $14-23^{\circ} \mathrm{C}$ reported by Casey \& Pratt (1985) and Curtis et al. (2014), respectively. Casey \& Pratt (1985) suggested that the north-south seasonal shift in the $15^{\circ} \mathrm{C}$ isotherm approximates the northern latitudinal limit for white shark distribution on the continental shelf and this appeared to be the case for our shelf-oriented sharks. In other regions, white sharks spend most of their time during their coastal phase in cooler water off California (10-14 ${ }^{\circ} \mathrm{C}$, Boustany et al. 2002, Weng et al. 2007a) and New Zealand (10-16 ${ }^{\circ} \mathrm{C}$, Francis et al. 2012), but in a similar temperature range at Guadalupe Island $\left(15-20^{\circ} \mathrm{C}\right.$, Domeier \& Nasby-Lucas 2008) and eastern Australia $\left(14-22^{\circ} \mathrm{C}\right.$, Bruce \& Bradford 2012).

On the continental shelf, white sharks in this study traversed the entire water column, but spent almost all their time $<50 \mathrm{~m}$ deep and more than half their time in the top $20 \mathrm{~m}$. During their acoustic track of a white shark off the coast of Long Island,

tween Cape Hatteras and the Gulf of Maine, with most individuals moving into the higher latitudes (Fig. 5). During the late fall, white sharks migrated south to the Southeast Shelf waters from North Carolina to Florida as far as the Gulf of Mexico. Movements between these 2 regions were relatively rapid from south to north in the late spring and early summer, but more gradual in the fall as the emigration from northern latitudes appeared to be staggered among individuals (Fig. 6). This broad-scale seasonal migration is typical of numerous temperate marine species on the US east coast, and has been well-documented in teleosts (Kneebone et al. 2014b), elasmobranchs (Kohler et al. 1998, Kneebone et al. 2014a), sea turtles (Eckert et al. 2006), and cetaceans (Kenney \& Winn 1986).

Based on historical white shark records, Casey \& Pratt (1985) and Curtis et al. (2014) suggested that this migration is driven by the interaction of seasonal temperature change and prey availability. During this study, we found that shelf-oriented white sharks occupied a consistent temperature range, spending
New York, Carey et al. (1982) found that the shark remained largely associated with the thermocline at approximately 10-20 m, but made periodic excursions to the bottom, which the authors attributed to foraging behavior. These vertical movements are similar to those of conspecifics in the Pacific Ocean. Juvenile white sharks spent most of their time at depths of $<100 \mathrm{~m}$ in the eastern North Pacific (Weng et al. 2007b) and off eastern Australia (Bruce et al. 2006, Bradford et al. 2012, Bruce \& Bradford 2012). This is consistent with the behavior of the 3 juveniles (<3.0 m TL, WS09-01, WS09-03, WS10-02) in our study, which exhibited strictly shelf movements and spending - with the exception of 3 excursions below $100 \mathrm{~m}$ (WS09-03) - all of their time <50 m deep.

The Northeast Shelf Ecosystem, which includes the Gulf of Maine and Georges Bank, is historically one of the most productive ecosystems in the world, supporting large numbers of fish, invertebrate, and cetacean species (Bigelow \& Schroeder 1953, Kenney \& Winn 1986, German 1987, Sherman et al. 1988, Fogarty \& Murawski 1998). Most recently, pinniped pop- 
ulations in this region have responded to more than $40 \mathrm{yr}$ of protection, and have increased dramatically in numbers while geographically expanding and recolonizing the Gulf of Maine (NMFS 2009, Wood LaFond 2009, Waring et al. 2016). These abundant resources on the Northeast Shelf, when coupled with warmer water temperatures during the summer, likely draw juvenile, subadult, and adult white sharks to this region to forage during the summer months. Diet information for the white shark in the WNA is limited, but stomach contents (Casey \& Pratt 1985) and stable isotope (Estrada et al. 2006, Hamady et al. 2014) analyses suggest that it is a generalist feeding on a variety of fishes and cetaceans with increasing trophic level through ontogeny (Estrada et al. 2006). Carey et al. (1982) hypothesized that dead whales are an important source of food for white sharks in the WNA due to the paucity of pinnipeds at the time of their study. Indeed, the scavenging of whale carcasses by white sharks in this region has been well-documented (Pratt et al. 1982, Casey \& Pratt 1985). However, the increasing abundance of pinnipeds, specifically gray seals, in the Gulf of Maine has attracted the attention of white sharks, which are now augmenting their diet with this prey (Skomal et al. 2012).

During the fall, tagged white sharks in this study moved along the shelf to southern overwintering habitat south of Cape Hatteras, North Carolina. Although pinnipeds are largely absent from this region, productivity on the Southeast Shelf (Cape Hatteras to Florida) peaks during the winter (Yoder et al. 1983), and this region supports diverse assemblages of tropical fauna as well as temperate species that overwinter in the region (Morley et al. 2017). This region also supports an abundant and diverse assemblage of cetaceans (Mullin \& Fulling 2003), including the North Atlantic right whale Eubalaena glacialis and bottlenose dolphins Tursiops truncatus truncatus. The coastal waters from northern Florida to southern North Carolina have been designated critical calving habitat for the North Atlantic right whale (Keller et al. 2012). In this region, white sharks have been documented scavenging adult right whales, and there is indirect evidence that they actively prey upon newborn calves in winter (Taylor et al. 2013). The overlap of white sharks with right whales in this habitat, as derived from our tag results, sightings records (Curtis et al. 2014), and direct observations (Taylor et al. 2013), suggests that right whales provide a viable food source for white sharks during the winter. There is also some evidence that white sharks are exploiting the shallow waters adjacent to productive river mouths and estuaries in this region, which support large numbers of bottlenose dolphins (Nekolny 2014, Waring et al. 2016). In this study, we observed 2 white sharks, one of which we tagged (WS13-01), in the winter off Jacksonville, Florida at the mouth of the St. John's River, and observed 2 others at the mouth of the St. Mary's river off Fernandina Beach, Florida, $34 \mathrm{~km}$ to the north (G. B. Skomal unpubl. data). There is ample evidence that white sharks prey upon small odontocetes, including dolphins and porpoises (reviewed by Heithaus 2001), and the remains of a dolphin have been documented in the stomach of a white shark sampled off Florida (Adams et al. 1994).

\section{Pelagic movements}

While the convergence on coastal habitats during summer by all size classes in our study indicates that the WNA shelf provides important foraging habitat for white sharks, $45 \%$ of our tagged sub-adults and adults also spent some fraction of each year in oceanic waters beyond the continental shelf. Similar behavior has been observed in white sharks tagged in the eastern North Pacific (Weng et al. 2007a,b, Jorgensen et al. 2010, 2012, Domeier 2012, Domeier \& Nasby-Lucas 2012), off South Africa (Bonfil et al. 2005), off Australia (Bruce et al. 2006, Bruce \& Bradford 2012, Werry et al. 2012), and off New Zealand (Duffy et al. 2012, Francis et al. 2012), with smaller individuals being largely restricted to coastal habitats and an ontogenetic shift toward increasing offshore movements with size. However, both Bruce \& Bradford (2012) and Duffy et al. (2012) have also observed the movements of juveniles (as small as $1.9 \mathrm{~m} \mathrm{TL}$ ) into pelagic habitat.

While the movement of white sharks into oceanic habitat is well-documented globally, this migratory behavior is generally more variable among study regions than the more ubiquitous patterns of coastal residency. For the white sharks tagged during this study, the use of pelagic habitat was not spatially, nor temporally, well-defined, and there was no apparent synchrony in their movement. With the exception of the summer months, during which they were on the shelf, pelagic behavior was observed throughout the year. In other regions, subadult and adult white sharks have a distinct coastal phase, spending much of the summer and fall in coastal waters off Guadalupe Island (Domeier \& Nasby-Lucas 2008), California (Weng et al. 2007a, Jorgensen et al. 2010), and New Zealand (Duffy et al. 2012), before making off- 
shore movements in the winter. These open-ocean movements are characterized by rapid, directed movements over deep water, and show some consistent migratory paths and destinations among individuals (Domeier \& Nasby-Lucas 2008, Bonfil et al. 2010, Jorgensen et al. 2010). In contrast, white sharks in South Africa (Bonfil et al. 2005) and Australia (Bruce et al. 2006, Bruce \& Bradford 2012) migrated between temperate and tropical waters largely along the shelf. Occasional forays took individuals into the open ocean, but without any generalizable pattern for the population.

Oceanic movements demonstrated by individuals in our study were even more disparate than those from South Africa and Australia (Fig. 3). In this study, white sharks moved throughout the WNA into chemically and biologically diverse temperate and subtropical habitats (McMahon et al. 2013), including the Gulf Stream, the Sargasso Sea, and the midAtlantic ridge. Individuals moved through $30^{\circ}$ of latitude with sea surface temperatures ranging from $4^{\circ} \mathrm{C}$ at $55^{\circ} \mathrm{N}$ in December to nearly $28^{\circ} \mathrm{C}$ at $25^{\circ} \mathrm{N}$ during the same month. Interestingly, 2 of the individuals that made the majority of the wide-ranging oceanic movements (WS13-01 and WS13-03) spent a considerable amount of time on and around the Grand Banks during fall and winter, with WS13-01 returning to the area 2 years in a row. It therefore appears white sharks are spending a significant amount of time in oceanic waters in the WNA, as has been hypothesized for white sharks in the Pacific.

Although high-tech tags allow researchers to follow the movements of white sharks into oceanic habitat, they do not reveal what these sharks are actually doing. It is generally thought that pelagic behavior is associated with foraging (Domeier 2012, Duffy et al. 2012), but mating has also been suggested (Jorgensen et al. 2010, 2012). In the eastern Pacific, subadult and adult white sharks move from coastal aggregation sites to a focal area referred to as the Shared Offshore Foraging Area (Domeier \& Nasby-Lucas 2008, 2012) or, more commonly, the White Shark Café (Weng et al. 2007a, Jorgensen et al. 2010). While in this area, white sharks make continuous rapid oscillatory dives presumably to feed at mesopelagic depths (Nasby-Lucas et al. 2009) or to mate (Jorgensen et al. 2012). However, during the relatively rapid migration to this area, white sharks exhibit a bimodal depth distribution, splitting their time between the surface and depths in excess of $300 \mathrm{~m}$ (Weng et al. 2007a, Nasby-Lucas et al. 2009, Jorgensen et al. 2012). This bimodal depth distribution was also observed in white sharks tagged off
New Zealand and South Africa when migrating across open ocean (Bonfil et al. 2005, Francis et al. 2012). Based on PSAT data, we found that white sharks that moved into oceanic waters of the Atlantic spent, on average, $77 \%$ of their time at the surface $(<25 \mathrm{~m})$ and at mesopelagic depths ( $>200 \mathrm{~m})$. It has been suggested that deep-diving behavior in white sharks is associated with prey searching and foraging, energy conservation, and navigation (reviewed by Francis et al. 2012). Our observation that white sharks in the WNA moved over broad expanses of the open ocean and appeared to target specific depths (Fig. 4) suggests foraging behavior. It is possible that the sharks were 'profiling' the water column to detect cues for navigation (Carey \& Scharold 1990, Klimley et al. 2002). However, considering the time spent at depth, we believe a more likely explanation is that the sharks are diving into the mesopelagic zone to forage (Howey et al. 2016). Oceanographic studies of the region (Irigoien et al. 2014, Fennell \& Rose 2015) have reported dense scattering layers throughout the WNA that presumably indicate high abundance of mesopelagic fish, squid, or crustaceans (Fennell \& Rose 2015). Pelagic movements exhibited by sharks in this study occupied the same regions (e.g. Fig. 4) and depth levels (Fig. 7) in which recent acoustic surveys (Sargasso Sea, Irigoien et al. 2014; Grand Banks to Ireland, Fennell \& Rose 2015) confirmed significant scattering layers from 200 to $600 \mathrm{~m}$ in the open ocean.

It does not appear that the vertical movements of white sharks in the WNA are limited significantly by water temperature. Temperature data logged by the PSAT tags indicated that white sharks spent $95 \%$ of their time within a broad temperature range of 11 to $27^{\circ} \mathrm{C}$ when in oceanic habitat with excursions into water as cold as $4^{\circ} \mathrm{C}$. Some of the lowest temperatures encountered by sharks in this study were by a large adult female (Fig. 4). The ability of this species (and other lamnid sharks) to occupy cold deep water is related to its endothermic capacity (Carey et al. 1982, 1985). It is likely that the horizontal and vertical niche expansion by subadult and adult white sharks into offshore habitat that we observed is related to increases in thermal inertia and thermoregulatory abilities associated with ontogeny (Neill et al. 1976).

One obvious biogeochemical difference between the North Pacific and North Atlantic oceans is the presence of cold hypoxic strata below a relatively shallow thermocline in the former that likely restricts the depth distribution of pelagic animals. Low dissolved oxygen (DO) levels $\left(\leq 2 \mathrm{ml} \mathrm{l}^{-1}\right)$ below the 
shallow thermocline is in stark contrast to the DO profiles of the WNA, which decline slowly from values that commonly exceed $4.0 \mathrm{ml} \mathrm{l}^{-1}$ (Stramma et al. 2008). Thus, while low DO has been hypothesized to compress vertical habitat of other pelagic fishes (Prince \& Goodyear 2006) and sharks (Abascal et al. 2011), the relatively high DO levels in the WNA do not appear to constrain the depth preferences of WNA white sharks.

\section{Life history in the WNA}

In the WNA, much of what is known about the natural history of the white shark comes from the opportunistic sampling of fisheries-dependent landings. Based on vertebral banding patterns and bomb radiocarbon, the species is slow-growing, lives in excess of $70 \mathrm{yr}$ (Hamady et al. 2014), and does not mature until much later $(26 \mathrm{yr}$ for males and $36 \mathrm{yr}$ for females; Natanson \& Skomal 2015) than original age/growth analyses suggested for other regions (Cailliet et al. 1985, Wintner \& Cliff 1999, Tanaka et al. 2011). Size at maturity and litter size remain unknown for females in the WNA because pregnant individuals have yet to be examined in this region. In this study, we have presumed that size at maturity in females is similar to that derived from samples collected in the Pacific and Indian oceans $(\sim 4.5 \mathrm{~m}$ TL, Francis 1996). Based on clasper morphology, Pratt (1996) estimated size at maturity in males to be $3.8 \mathrm{~m} \mathrm{TL}$ in the WNA. Observations of mating behavior and parturition are lacking for white sharks, but it has been suggested, based on numerous capture records of young-of-the-year $(\sim 135 \mathrm{~cm}$ TL, Natanson \& Skomal 2015) and juvenile white sharks, that the New York Bight (off New York and New Jersey) provides important nursery habitat during the spring and summer (Casey \& Pratt 1985, Curtis et al. 2014). These records also suggest that parturition occurs in the spring and summer months. Our observation that all tagged white sharks, including the return of pelagic adult females, were shelforiented during the summer months (Table 1, Fig. 5) suggests coastal parturition. However, we have no evidence that adult females aggregate in the New York Bight to give birth to their young. Although more adult females need to be tagged, our findings suggest that young-of-the-year white sharks are not born in the New York Bight, but simply migrate into this nursery habitat, like older juveniles (Curtis et al. 2014), to take advantage of rich foraging opportunities (Casey \& Pratt 1985).
The results of this study, when coupled with previously reported capture records (Casey \& Pratt 1985, Curtis et al. 2014), indicate that the continental shelf along the US east coast provides important foraging habitat for juvenile, subadult, and adult white sharks. It is also likely that adult white sharks mate opportunistically while on the shelf, but mating grounds have yet to be identified. Domeier (2012) suggested that mating occurs at adult aggregation sites in the eastern North Pacific during the coastal phase (summer and fall). While males return annually to these sites, it has been suggested that females maintain a 2-year reproductive cycle (Anderson \& Pyle 2003; although see Chapple et al. 2016), during which they remain, while pregnant, in offshore habitat over a broad geographic area before returning to coastal waters for parturition (Domeier 2012, Domeier \& Nasby-Lucas 2012). In the WNA, we found that all of our adult white sharks were present on the shelf during the summer months. Pratt (1996) suggested that mating occurs in the coastal waters off the northeastern USA. The co-occurrence of adult white sharks of both sexes in this region supports this hypothesis and fresh wounds possibly associated with mating have been observed on large females foraging at the white shark aggregation site off Cape Cod (G. B. Skomal \& J. H. Chisholm unpubl. data). However, the adults of both sexes overlap throughout their coastal range, so it is also plausible that mating is more temporally and spatially opportunistic and not restricted to northeastern waters. Although evidence for sperm storage is lacking in lamnid sharks (Pratt 1993), opportunistic mating, sperm storage, and delayed fertilization would enhance reproductive success in this apex predator.

Adults of both sexes exhibited offshore movements during the fall, winter, and spring, but the most expansive movements were made by 3 adult females (WS12-17, WS13-01, WS13-03). These extensive movements into oceanic waters may be associated with sexual segregation as a means for pregnant females to refuge from costly mating activities (Wearmouth \& Sims 2008). Clearly, additional research is needed to further test this hypothesis. However, we must also acknowledge the limitations of our sample size and the need to tag additional white sharks to further investigate these movements.

\section{Population dynamics and implications}

Mounting evidence for the global phylogeography of the white shark suggests a complex population 
structure. Phylogenetic analyses of mtDNA control regions support 2 main lineages in (1) the IndoPacific and the Mediterranean, and (2) South Africa and the WNA (Pardini et al. 2001, Jorgensen et al. 2010, Gubili et al. 2011). Within these groups, there is some evidence that WNA sharks are distinct from South African haplotypes (O'Leary et al. 2015, Andreotti et al. 2016). Gubili et al. (2011) noted some similarity between western Indo-Pacific and Mediterranean haplotypes, suggesting that the Mediterranean white shark population was founded by individuals from the Pacific during the Late Pleistocene. Clearly, white sharks are capable of migrations across ocean basins. Yet such movements may be rare, as even low levels of connectivity across the North Atlantic would act to homogenize haplotype frequencies between the WNA and Mediterranean populations. Our results generally support the hypothesis of limited genetic connectivity between Atlantic populations, as even the most wide-ranging shark in the study only traveled as far east as the MidAtlantic Ridge and the Azores.

In the WNA, several studies have reported declining white shark populations in the mid- to late $20^{\text {th }}$ century from pelagic longline logbook data (Baum et al. 2003), opportunistic capture and sightings (McPherson \& Myers 2009, Curtis et al. 2014), and genetics (O'Leary et al. 2015). Most recent information, however, suggests apparent increases in sightings (Skomal et al. 2012) and abundance (Curtis et al. 2014). These increases may be at least partially attributed to legal protection prohibiting white sharks from harvest in the WNA since the late 1990s; however, seascape-scale movements of large females demonstrate the importance of international coordination of management efforts to protect these highly mobile predators.

Acknowledgements. We gratefully thank our fishing and tagging vessels: Captain Bill Chaprales, Nick Chaprales, and George Breen of the F/V Ezyduzit; Christopher Fischer, Captain Brett McBride, and the crew of the M/V Ocearch; and Captain John King, Pam King, Cynthia Wigren, and Wayne Davis of the F/V Aleutian Dream. This research was carried out under Exempted Fishing Permits (SHK-EFP-1104, SHK-EFP-12-08，SHK-EFP-13-01，SHK-EFP-14-03) issued to the Massachusetts Division of Marine Fisheries by the NMFS Highly Migratory Species Management Division. This research was funded by Federal Aid in Sport Fish Restoration, the National Science Foundation (OCE-0825148), the John J. Sacco and Edith L. Sacco Charitable Foundation, the Atlantic White Shark Conservancy, the Massachusetts Environmental Trust, Discovery Communications, National Geographic, and the Woods Hole Oceanographic Institution. This is Massachusetts Division of Marine Fisheries Contribution No. 90.

\section{LITERATURE CITED}

Abascal FJ, Quintans M, Ramos-Cartelle A, Mejuto J (2011) Movements and environmental preferences of the shortfin mako, Isurus oxyrinchus, in the southeastern Pacific Ocean. Mar Biol 158:1175-1184

Adams DH, Mitchell ME, Parsons GR (1994) Seasonal occurrence of the white shark, Carcharodon carcharias, in waters off the Florida west coast, with notes on its life history. Mar Fish Rev 56:24-28

Anderson SD, Pyle P (2003) A temporal, sex-specific occurrence pattern among white sharks at the South Farallon Islands, California. Calif Fish Game 89:96-101

Andreotti S, Von Der Heyden S, Henriques R, Rutzen M, Meÿer M, Oosthuizen H, Matthee CA (2016) New insights into the evolutionary history of white sharks, Carcharodon carcharias. J Biogeogr 43:328-339

Baum JK, Myers RA, Kehler DG, Worm B, Harley SJ, Doherty PA (2003) Collapse and conservation of shark populations in the Northwest Atlantic. Science 80299: 389-392

Bigelow HB, Schroeder WC (1948) Fishes of the western North Atlantic. Part 1 (lancelets, cyclostomes, sharks). Yale University Press, New Haven, CT

Bigelow HB, Schroeder WC (1953) Sawfishes, guitarfishes, skates and rays. Sears Foundation for Marine Research, Yale University Press, New Haven, CT

Bonfil R, Meyer M, Scholl MC, Johnson R and others (2005) Transoceanic migration, spatial dynamics, and population linkages of white sharks. Science 310:100-103

* Bonfil R, Francis MP, Duffy C, Manning MJ, O'Brien S (2010) Large-scale tropical movements and diving behavior of white sharks Carcharodon carcharias tagged off New Zealand. Aquat Biol 8:115-123

* Boustany AM, Davis SF, Pyle P, Anderson SD, Le Boeuf BJ, Block BA (2002) Expanded niche for white sharks. Nature 415:35-36

Bradford RW, Hobday AJ, Bruce BD (2012) Identifying juvenile white shark behaviour from electronic tag data. In: Domeier ML (ed) Global perspectives on the biology and life history of the white shark. CRC Press, Boca Raton, FL, p 255-270

Bruce BD, Bradford RW (2012) Habitat use and spatial dynamics of juvenile white sharks, Carcharodon carcharias, in eastern Australia. In: Domeier ML (ed) Global perspectives on the biology and life history of the white shark. CRC Press, Boca Raton, FL, p 225-254

*Buce BD, Stevens JD, Malcolm H (2006) Movements and swimming behaviour of white sharks (Carcharodon carcharias) in Australian waters. Mar Biol 150:161-172

Cailliet GM, Natanson LJ, Welden BA, Ebert DA (1985) Preliminary studies on the age and growth of the white shark, Carcharodon carcharias, using vertebral bands. Mem South Calif Acad Sci 9:49-60

* Carey FG, Scharold JV (1990) Movements of blue sharks (Prionace glauca) in depth and course. Mar Biol 106: 329-342

Carey FG, Kanwisher JW, Brazier O, Gabrielson G, Casey JG, Pratt HL (1982) Temperature and activities of a white shark, Carcharodon carcharias. Copeia 254-260

Carey FG, Casey JG, Pratt HL, Urquhart D, McCosker JE (1985) Temperature, heat production, and heat exchange in lamnid sharks. Mem South Calif Acad Sci 9:92-108

Casey JG, Pratt HL (1985) Distribution of the white shark, Carcharodon carcharias, in the western North Atlantic. 
Mem South Calif Acad Sci 9:2-14

Castro JI (2011) The sharks of North America. Oxford University Press, New York, NY

Chapple TK, Chambert T, Kanive PE, Jorgensen SJ and others (2016) A novel application of multi-event modeling to estimate class segregation in a highly migratory oceanic vertebrate. Ecology 97:3494-3502

Chaprales W, Lutcavage M, Brill R, Chase B, Skomal G (1998) Harpoon method for attaching ultrasonic and 'popup' satellite tags to giant bluefin tuna and large pelagic fishes. Mar Technol Soc J 32:104-105

CLS (2016) Argos user manual. www.argos-system.org/ manual

Compagno LJV (1984) FAO Species Catalogue. IV. Sharks of the World. 1. Hexanchiformes to Laminiformes. FAO, Rome

Curtis TH, McCandless CT, Carlson JK, Skomal GB and others (2014) Seasonal distribution and historic trends in abundance of white sharks, Carcharodon carcharias, in the western North Atlantic ocean. PLOS ONE 9:e99240

Domeier ML (2012) A new life history hypothesis for white sharks, Carcharodon carcharias, in the Northeastern Pacific. In: Domeier ML (ed) Global perspectives on the biology and life history of the white shark. CRC Press, Boca Raton, FL, p 199-224

Domeier ML, Nasby-Lucas N (2008) Migration patterns of white sharks Carcharodon carcharias tagged at Guadalupe Island, Mexico, and identification of an eastern Pacific shared offshore foraging area. Mar Ecol Prog Ser 370:221-237

Domeier ML, Nasby-Lucas N (2012) Sex-specific migration patterns and sexual segregation of adult white sharks, Carcharodon carcharias, in the Northeastern Pacific. In: Domeier ML (ed) Global perspectives on the biology and life history of the white shark. CRC Press, Boca Raton, FL, p 133-146

* Domeier ML, Nasby-Lucas N (2013) Two-year migration of adult female white sharks (Carcharodon carcharias) reveals widely separated nursery areas and conservation concerns. Anim Biotelem 1:2, doi:10.1186/2050-3385-1-2

Duffy CAJ, Francis MP, Manning MJ, Bonfil R (2012) Regional population connectivity, oceanic habitat, and return migration revealed by satellite tagging of white sharks, Carcharodon carcharias, at New Zealand aggregation sites. In: Domeier ML (ed) Global perspectives on the biology and life history of the white shark. CRC Press, Boca Raton, FL, p 301-318

Eckert SA, Bagley D, Kubis S, Ehrhart L, Johnson C, Stewart $\mathrm{K}$, DeFreese D (2006) Internesting and postnesting movement and foraging habitat of leatherback sea turtles (Dermochelys coriacea) nesting in Florida. Chelonian Conserv Biol 5:239-248

Estrada JA, Rice AN, Natanson LJ, Skomal GB (2006) Use of isotopic analysis of vertebrae in reconstructing ontogenetic feeding ecology in white sharks. Ecology 87: 829-834

Fennell S, Rose G (2015) Oceanographic influences on Deep Scattering Layers across the North Atlantic. Deep Sea Res I 105:132-141

* Fogarty MJ, Murawski SA (1998) Large-scale disturbance and the structure of marine systems: fishery impacts on Georges Bank. Ecol Appl 8:S6-S22

Francis M (1996) Observation on a pregnant white shark with a review of reproductive biology. In: Klimley AP, Ainley DG (eds) Great white sharks: the biology of
Carcharodon carcharias. Academic Press, San Diego, CA, p 157-172

Francis MP, Duffy CAJ, Bonfil R, Manning MJ (2012) The third dimension: vertical habitat use by white sharks, Carcharodon carcharias in New Zealand and in oceanic and tropical waters of the Southwest Pacific Ocean. In: Domeier ML (ed) Global perspectives on the biology and life history of the white shark. CRC Press, Boca Raton, FL, p 319-342

German AW (1987) History of the early fisheries: 1720-1930. In: Backus R (ed) Georges Bank Massachusetts Inst Technol Press, Cambridge, MA, p 409-424

Gubili C, Bilgin R, Kalkan E, Karhan SÜ and others (2011) Antipodean white sharks on a Mediterranean walkabout? Historical dispersal leads to genetic discontinuity and an endangered anomalous population. Proc R Soc B 278:1679-1686

Hamady LL, Natanson LJ, Skomal GB, Thorrold SR (2014) Vertebral bomb radiocarbon suggests extreme longevity in white sharks. PLOS ONE 9:e84006

*Heithaus MR (2001) Predator-prey and competitive interactions between sharks (order Selachii) and dolphins (suborder Odontoceti): a review. J Zool (Lond) 253:53-68

*Howey LA, Tolentino ER, Papastamatiou YP, Brooks EJ and others (2016) Into the deep: the functionality of mesopelagic excursions by an oceanic apex predator. Ecol Evol 6:5290-5304

* Irigoien X, Klevjer TA, Røstad A, Martinez U and others (2014) Large mesopelagic fishes biomass and trophic efficiency in the open ocean. Nat Commun 5:3271

Johnson R, Bester MN, Dudley SF, Oosthuizen WH, Meÿer M, Hancke L, Gennari E (2009) Coastal swimming patterns of white sharks (Carcharodon carcharias) at Mossel Bay, South Africa. Environ Biol Fishes 85:189-200

Jorgensen SJ, Reeb CA, Chapple TK, Anderson S and others (2010) Philopatry and migration of Pacific white sharks. Proc R Soc B 277:679-688

Jorgensen SJ, Arnoldi NS, Estess EE, Chapple TK, Rückert M, Anderson SD, Block BA (2012) Eating or meeting? Cluster analysis reveals intricacies of white shark (Carcharodon carcharias) migration and offshore behavior. PLOS ONE 7:e47819

Keller CA, Garrison L, Baumstark R, Ward-Geiger LI, Hines E (2012) Application of a habitat model to define calving habitat of the North Atlantic right whale in the southeastern United States. Endang Species Res 18:73-87

Kenney RD, Winn HE (1986) Cetacean high-use habitats of the northeast United States continental shelf. Fish Bull 84:345-357

Klimley AP, Ainley DG (1996) Great white sharks: the biology of Carcharodon carcharias. Academic Press, San Diego, CA

Klimley AP, Le Boeuf BJ, Cantara KM, Richert JE, Davis SF, Sommeran SV, Kelly JT (2001) The hunting strategy of white sharks (Carcharodon carcharias) near a seal colony. Mar Biol 138:617-636

Klimley AP, Beavers SC, Curtis TH, Jorgensen SJ (2002) Movements and swimming behavior of three species of sharks in La Jolla Canyon, California. Environ Biol Fishes 63:117-135

Kneebone J, Chisholm J, Skomal G (2014a) Movement patterns of juvenile sand tigers (Carcharias taurus) along the east coast of the USA. Mar Biol 161:1149-1163

Kneebone J, Hoffman WS, Dean MJ, Fox DA, Armstrong MP (2014b) Movement patterns and stock composition 
of adult striped bass tagged in Massachusetts coastal waters. Trans Am Fish Soc 143:1115-1129

Kohler NE, Casey JG, Turner PA (1998) NMFS cooperative shark tagging program, 1962-93: an atlas of shark tag and recapture data. Mar Fish Rev 60:1-87

McMahon KW, Hamady LL, Thorrold SR (2013) Ocean ecogeochemistry: a review. Oceanogr Mar Biol Annu Rev 51:327-374

*McPherson JM, Myers RA (2009) How to infer population trends in sparse data: examples with opportunistic sighting records for great white sharks. Divers Distrib 15: 880-890

Morley JW, Batt RD, Pinsky ML (2017) Marine assemblages respond rapidly to winter climate variability. Glob Chang Biol 23:2590-2601

Mullin KD, Fulling GL (2003) Abundance of cetatceans in the southern US North Atlantic Ocean during summer 1998. Fish Bull 101:603-613

Nasby-Lucas N, Dewar H, Lam CH, Goldman KJ, Domeier ML (2009) White shark offshore habitat: a behavioral and environmental characterization of the eastern Pacific shared offshore foraging area. PLOS ONE 4:e8163

Natanson LJ, Skomal GB (2015) Age and growth of the white shark, Carcharodon carcharias, in the western North Atlantic Ocean. Mar Freshw Res 66:387-398

Neill WH, Chang RKC, Dizon AE (1976) Magnitude and ecological implications of thermal inertia in skipjack tuna, Katsuwoaus pelamis (Linnaeus). Environ Biol Fishes 1:61-80

Nekolny SR (2014) The effects of sampling design on abundance and distribution of bottlenose dolphins in the St. Johns River, Florida. MSc thesis, University of North Florida, Jacksonville, FL

NMFS (2009) Gray seal (Halichoerus grypus): western North Atlantic stock. Silver Spring, MD

O'Leary SJ, Feldheim KA, Fields AT, Natanson LJ and others (2015) Genetic diversity of white sharks, Carcharodon carcharias, in the Northwest Atlantic and Southern Africa. J Hered 106:258-265

Pardini AT, Jones CS, Noble LR, Kreiser B and others (2001) Sex-biased dispersal of great white sharks. Nature 412: 139-140

Pratt HL (1993) The storage of spermatozoa in the oviducal glands of western North Atlantic sharks. Environ Biol Fishes 38:139-149

Pratt HL (1996) Reproduction in the male white shark. In: Klimley AP, Ainley DG (eds) Great white sharks: the biology of Carcharodon carcharias. Academic Press, San Diego, CA, p 131-138

Pratt HL, Casey JG, Conklin RB (1982) Observations on large white sharks, Carcharodon carcharias, off Long Island, New York. Fish Bull 80:153-156

Prince ED, Goodyear CP (2006) Hypoxia-based habitat compression of tropical pelagic fishes. Fish Oceanogr 15: 451-464

R Development Core Team (2015) R: a language and environment for statistical computing. R Foundation for Statistical Computing, Vienna

Sherman K, Grosslein M, Mountain D, Busch D, O'Reilly J, Theroux R (1988) The continental shelf ecosystem off the northeast coast of the United States. In: Postema H, Zijl-

Editorial responsibility: Scott Shaffer,

San Jose, California, USA stra JJ (eds) Ecosystems of the world 27: continental shelves. Elsevier Press, Amsterdam, p 279-337

Skomal GB, Chisholm J, Correia SJ (2012) Implications of increasing pinniped populations on the diet and abundance of white sharks off the coast of Massachusetts. In: Domeier ML (ed) Global perspectives on the biology and life history of the white shark. CRC Press, Boca Raton, FL, p 405-418

Stramma L, Johnson GC, Sprintall J, Mohrholz V (2008) Expanding oxygen-minimum zones in the tropic oceans. Science 320:655-658

Strong WR Jr, Murphy RC, Bruce BD, Nelson DR (1992) Movements and associated observations of bait-attracted white sharks, Carcharadon carcharias: a preliminary report. Aust J Mar Freshw Res 43:13-20

Sumner MD, Luque S (2015) Spatial analysis of animal track data in R: the trip package. https://github.com/mdsumner/ trip

Tanaka S, Kitamura T, Mochizuki T, Kofuji K (2011) Age, growth and genetic status of the white shark (Carcharodon carcharias) from Kashima-nada, Japan. Mar Freshw Res 62:548-556

Taylor JKD, Mandelman JW, McLellan WA, Moore MJ, Skomal GB, Rotstein DS, Kraus SD (2013) Shark predation on North Atlantic right whales (Eubalaena glacialis) in the southeastern United States calving ground. Mar Mamm Sci 29:204-212

Templeman W (1963) Distribution of sharks in the Canadian Atlantic (with special reference to Newfoundland waters). Bull Fish Res Board Can 140:1-77

Waring GT, Josephson E, Maze-Foley K, Rosel PE (2016) US Atlantic and Gulf of Mexico marine mammal stock assessments - 2015. NOAA Tech Memo, NMFS NE 238

Wearmouth VJ, Sims DW (2008) Sexual segregation in marine fish, reptiles, birds and mammals: behaviour patterns, mechanisms and conservation implications. Adv Mar Biol 54:107-170

*Weng KC, Boustany AM, Pyle P, Anderson SD, Brown A, Block BA (2007a) Migration and habitat of white sharks (Carcharodon carcharias) in the eastern Pacific Ocean. Mar Biol 152:877-894

*Weng KC, O'Sullivan JB, Lowe CG, Winkler CE, Dewar H, Block BA (2007b) Movements, behavior and habitat preferences of juvenile white sharks Carcharodon carcharias in the eastern Pacific. Mar Ecol Prog Ser 338:211-224

Werry JM, Bruce B, Sumpton W, Reid D, Mayer D (2012) Beach areas used by juvenile white shark in eastern Australia. In: Domeier ML (ed) Global perspectives on the biology and life history of the white shark. CRC Press, Boca Raton, FL, p 271-287

Wintner SP, Cliff G (1999) Age and growth determination of the white shark, Carcharodon carcharias, from the east coast of South Africa. Fish Bull 97:153-169

Wood LaFond S (2009) Dynamics of recolonization: a study of the gray seal (Halichoerus grypus) in the northeast US. $\mathrm{PhD}$ dissertation, University of Massachusetts, Boston, MA

Yoder JA, Atkinson LP, Bishop SS, Hofmann EE, Lee TN (1983) Effect of upwelling on phytoplankton productivity of the outer southeastern United States continental shelf. Cont Shelf Res 1:385-404

Submitted: March 9, 2017; Accepted: August 11, 2017

Proofs received from author(s): September 20, 2017 